\title{
Stock Price Reactions on NASDAQ Stock Exchange for Special Dividend Announcements
}

\author{
Arian Seyedimany ${ }^{a^{*}}$ \\ ${ }^{a}$ Eastern Mediterranean University, Famagusta, Norrth Cyprus
}

\begin{abstract}
Announcing dividend pay-out policy by a company will signals market firm's future prospects and changes its stock prices according to dividend signalling theory. By analysis the effect of special dividend announcements for 5 companies listed in NASDAQ for the period of 2014-2018, this study investigates the stock price reactions to special dividend announcement for 40 days around the event and challenges dividend signalling theory. The empirical results calculated both in discrete and logarithmic forms. Only few disordered significant abnormal returns and average abnormal returns occurred according to the t-test. The results show that shareholders do not gain value from announcement of special dividend in NASDAQ stock exchange market. That Results indicated from adjusted market model in this research do not support dividend-signalling theory Hence do not confirm that the announcement of dividend has significant effect on price of shares. In general the results consistent with the Miller and Modigliani (1961) dividend irrelevance hypothesis.
\end{abstract}

Keywords:

Abnormal Returns;

Event Study;

Dividend Announcement;

Market Adjusted Model.

Article History:

$\begin{array}{llll}\text { Received: } & 18 & \text { July } & 2019 \\ \text { Accepted: } & 07 & \text { October } & 2019 \\ & & & 2019\end{array}$

\section{1- Introduction}

The goal of financial managers is to maximizing shareholders wealth. Financial managements, target to maximize a company's value, which quantifies by the price of its stock. This aim may achieve by paying shareholders dividends, however this subject is still unsolved. It is often debate about the impact of dividend policy on stockholders wealth. There are many researches about information asymmetry between investors and managers. Dividends signal investors about the future performances of companies. Previous studies found that stock prices react positively once there is announcement of dividend increases and, also it react negatively once there is decrease in dividend payout in a company. There are many literatures though, claim that no abnormal return would occur by declaration of dividend via a company. The myth still remains that if paying out by a company would really generate shareholders' value or not. This paper aims to see if stock prices react once special dividends announces.

\section{2- Literature Review}

Many empirical and theoretical researches on the effect of dividend has been done recently. Cash dividend is a reward to shareholders of a company and this reward will be offsets with the stock value reduction in the company [1]. In a perfect world (no restriction and taxes) paying out dividend has no effect on the value of shareholders [2]. In reality though, altering the dividend policy would often follows by stocks market value changes. Gordon (1959) and Walter (1956) suggesting that present value of all future dividends will reflect on current price of stock [3, 4]. Brennan (1979) and Litzenberger (1979) On the other hand, indicated that once marginal tax rate is bigger than zero, receiving dividend would not be optimal as investor's perspective and systematic risk and dividend yield would be determinative [5, 6]. As Ross (1977) in dividend signaling theory says, firms which increase their dividend payments significantly had a

\footnotetext{
* CONTACT: Arian.imani@gmail.com

DOI: http://dx.doi.org/10.28991/esj-2019-01200
}

(C) 2019 by the authors. Licensee ESJ, Italy. This is an open access article under the terms and conditions of the Creative Commons Attribution (CC-BY) license (https://creativecommons.org/licenses/by/4.0/). 
corresponding rise in their share prices while those firms which reduce or omit dividend payment significantly, had a corresponding reduction in their share prices [7]. In this regards, some studies found significant positive relationship of paying out dividend and stock price [8-10]. In addition others suggested that this relationship is negative [11]. Sealy (1987) found that dividend announcement on Johannesburg Stock Exchange sends market little or no information thus the role of signaling is questionable on the phenomenon of dividend [12]. Uddin and Chowdhury (2005) also examine dividend announcements for Stock Exchange of Dhaka and found that there were no significant abnormal returns statistically and dividend has no content of information for stocks' prices and returns [13]. Nevertheless this issue is still controversial among recent studies. A study on 196 dividend announcements of 1996 to 2004 for Tunisian Securities exchange shows inconsistent results with signaling theory [14]. Chatterjee and Dutta (2017) also found no abnormal returns generated by the announcement of cash dividend by studying 210 dividend announcements of National Stock Exchange of India Ltd [15]. Legenzova (2017) likewise found no statistically significant abnormal returns of NASDAQ OMX Baltic market which paid out dividends during 2010-2005 [16]. On the other hand there are studies that support signaling theory. Felimban (2018) found partially supports for signaling hypothesis in Gulf countries stock market [17]. Chaabouni (2017) found that high dividend pay outs sign shareholders positively in Saudi Arabia Financial Markets [18]. A study on the Nigerian Stock Exchange also supported the signaling hypothesis [19]. Furthermore significant abnormal returns have also be shown by other studies [20]. As the literature about the effect of dividend has been developed well theoretically, this puzzle needs to be more investigated and explained that why firms still pay out dividends as until now no consensus was found. This study examines the effect of special dividend announcement on stock returns in NASDAQ stock market over period of 2014 to 2018. Therefore, by investigating one of the most reliable stock markets this study inspects whether announcing special dividend by NASDAQ companies contributes to abnormal return or not.

\section{3-Methodology}

The aim of this study is to investigate stock prices reaction to dividend announcement by using market adjusted returns methodology to discover stock return abnormality nearby dividend announcement period (Dividend window). Event study is a technique to assess the impact of specific event on stock price as announcing dividend and return of stock [21].

For the empirical evidence five companies from NASDAQ stock exchange which paid out special dividend during 2014 to 2018 have been sampled randomly in this study (Table 1). The companies declared special dividend have been found from NASDAQ website. Daily data for share prices of each company were collected from yahoo finance and NASDAQ website information services. Share returns are based on adjusted closed share prices from 200 days before the event to 30 days after the event which obtained from yahoo finance website. The data characterized based on event time, with day zero determined as announcement day for special dividend.

Table 1. Dividend history for five selected corporations.

\begin{tabular}{cccc}
\hline No. & Company name & Announcement date & Amount of special dividend in \$ \\
\hline 1 & Equinix, Inc. & $9 / 28 / 2015$ & 10.95 \\
2 & Amerco CO. & $8 / 28 / 2015$ & 3 \\
3 & CME Group Inc. & $12 / 6 / 2017$ & 3.5 \\
4 & KLA-Tencor Co. & $11 / 19 / 2014$ & 16.5 \\
5 & T. Rowe Price Group, Inc. & $2 / 19 / 2015$ & 2 \\
\hline
\end{tabular}

Note: data collected from [22].

Market adjusted return model has been used for the impact of special dividends on prices of shares.

$A R_{i t}=R_{i t}-R_{m t}$

Where:

$\mathrm{AR}_{\mathrm{it}}=$ Abnormal return of share $\mathrm{i}$ over day $\mathrm{t}$

$\mathrm{R}_{\mathrm{it}}=$ Actual return of share $\mathrm{i}$ over day $\mathrm{t}$

$\mathrm{R}_{\mathrm{mt}}=$ daily Market return on day $\mathrm{t}$

The model is used for each events in three time frames. 20 days before and 20 days after day 0 for event window. 180 days before event window for estimation window and 10 days after event window for post event window. The concern time range is before and after the date of event in order to determine the effect of announcements on price, which occurs once, stock market closes on day 0 [23]. To test statistic on event window, abnormal returns has been standardized by standard deviation estimated during estimation period. 
To testing following hypothesizes;

H1: No statistically significant abnormal returns by reason of special dividend announcement during event window.

H2: The cumulative abnormal returns by reason of special dividend announcement are statistically insignificant during event window.

Firstly, this study assesses the impact of dividend announcement on a firm's value for pre and post-event abnormal returns both in discrete and logarithmic forms. Secondly, by calculating average abnormal returns and cumulative abnormal returns (CAR), this study will assesses the impact of divided announcement on the share prices of a sample of 5 corporations. CAR is compute by combining daily abnormal returns starting beforehand day 0 (dividend announcement) to after the day 0.

$C A R_{i t}=\sum A R_{i t}$

In conclusion, the results of statistical significance of AR and CAR will describe.

\section{4- Empirical Results}

In this study the findings are based on event study methodology which abnormal returns are investigated to see the effect of divided announcement on stock prices. Table 2 shows abnormal returns of 41 days of event window ( 20 days prior and 20 days post event) to dividend announcement of a corporation. Market adjusted abnormal return on the dividend announcement day was only 0.2 percent and not statistically significant. Leaking information prior the announcement made by the company may be the reason for that. Once such leakages happens the announcement of dividend carries no shock to the market. A positive significant abnormal returns of 0.28 and 0.31 percent two and five days before the dividend announcement respectfully, according to the t-test, shows that market reacted earlier than the actual announcement of the dividend.

Table2. Abnormal returns $\left(A R_{s}\right) \&$ t-values of stocks using both discrete and logarithmic returns for one corporation.

\begin{tabular}{|c|c|c|c|c|}
\hline \multirow{2}{*}{ Days } & \multicolumn{2}{|c|}{ Discrete returns } & \multicolumn{2}{|c|}{ Logarithmic returns } \\
\hline & $\mathbf{A} \mathbf{R}_{\mathrm{s}}$ & t-test & $\mathbf{A} \mathbf{R}_{\mathrm{s}}$ & t-test \\
\hline-20 & -0.002 & -0.165 & -0.002 & -0.166 \\
\hline-19 & -0.003 & -0.277 & -0.003 & -0.277 \\
\hline-18 & 0.009 & 0.888 & 0.009 & 0.888 \\
\hline-17 & -0.001 & -0.128 & -0.001 & -0.128 \\
\hline-16 & 0.015 & 1.535 & 0.015 & 1.523 \\
\hline-15 & 0.003 & 0.325 & 0.003 & 0.325 \\
\hline-14 & 0.001 & 0.091 & 0.001 & 0.090 \\
\hline-13 & -0.010 & -0.989 & -0.010 & -0.991 \\
\hline-12 & -0.003 & -0.271 & -0.003 & -0.273 \\
\hline-11 & 0.016 & 1.597 & 0.016 & 1.585 \\
\hline-10 & -0.006 & -0.573 & -0.006 & -0.575 \\
\hline-9 & -0.006 & -0.564 & -0.006 & -0.566 \\
\hline-8 & -0.003 & -0.322 & -0.003 & -0.322 \\
\hline-7 & 0.003 & 0.300 & 0.003 & 0.300 \\
\hline-6 & 0.017 & 1.641 & 0.016 & 1.621 \\
\hline-5 & 0.031 & $3.114 *$ & 0.031 & $3.101 *$ \\
\hline-4 & 0.004 & 0.427 & 0.004 & 0.421 \\
\hline-3 & 0.012 & 1.210 & 0.012 & 1.208 \\
\hline-2 & 0.028 & $2.769^{*}$ & 0.028 & $2.758^{*}$ \\
\hline-1 & -0.007 & -0.648 & -0.007 & -0.652 \\
\hline
\end{tabular}




\begin{tabular}{|c|c|c|c|c|}
\hline 0 & 0.002 & 0.209 & 0.002 & 0.209 \\
\hline 1 & -0.006 & -0.547 & -0.006 & -0.547 \\
\hline 2 & 0.001 & 0.093 & 0.001 & 0.091 \\
\hline 3 & -0.006 & -0.579 & -0.006 & -0.580 \\
\hline 4 & 0.004 & 0.392 & 0.004 & 0.392 \\
\hline 5 & -0.011 & -1.115 & -0.011 & -1.121 \\
\hline 6 & -0.005 & -0.500 & -0.005 & -0.504 \\
\hline 7 & -0.007 & -0.729 & -0.007 & -0.731 \\
\hline 8 & -0.007 & -0.694 & -0.007 & -0.695 \\
\hline 9 & -0.003 & -0.296 & -0.003 & -0.299 \\
\hline 10 & -0.004 & -0.434 & -0.004 & -0.436 \\
\hline 11 & 0.009 & 0.893 & 0.009 & 0.889 \\
\hline 12 & -0.012 & -1.172 & -0.012 & -1.181 \\
\hline 13 & 0.003 & 0.311 & 0.003 & 0.312 \\
\hline 14 & 0.003 & 0.304 & 0.003 & 0.303 \\
\hline 15 & 0.001 & 0.090 & 0.001 & 0.090 \\
\hline 16 & 0.005 & 0.491 & 0.005 & 0.492 \\
\hline 17 & -0.024 & $-2.342^{*}$ & -0.024 & $-2.349^{*}$ \\
\hline 18 & 0.008 & 0.759 & 0.008 & 0.748 \\
\hline 19 & 0.009 & 0.885 & 0.009 & 0.880 \\
\hline 20 & -0.002 & -0.175 & -0.002 & -0.177 \\
\hline
\end{tabular}

Table 3 shows cumulative abnormal returns of stocks for one corporation. At the top CARs prior to announcement date are stated. The results show that the firm experienced positive not statistically significant CARs prior to announcement date during event windows of $(-10,-1)$ and $(-5,-1)$. On the other hand CARs around the announcement date, on $(0,1),(0,5)$ and $(0,10)$ periods, are negative but also statistically insignificant. For after dividend announcement periods $(2,5)$ and $(2,10)$, CARs are also negative and statistically insignificant for the firm. Results indicated that in all the three time periods including pre, around and post-announcement, CARs are all statistically insignificant for the firm hence it reveals that dividend announcement do not gain shareholders' value of the firm and it consists with Miller and Modigliani (1961) dividend irrelevance hypothesis [1].

Table3. Cumulative abnormal returns (CARs) \& t-values of stocks using both discrete and logarithmic returns for one corporation

\begin{tabular}{cccccc}
\hline \multirow{2}{*}{ Period (days) } & Length & \multicolumn{2}{c}{ Discrete returns } & \multicolumn{2}{c}{ Logarithmic returns } \\
\cline { 3 - 5 } & & CARs & t-value & CARs & t-value \\
\hline$(-10,-1)$ & 10 & 0.0742 & -0.0012 & 0.0734 & -0.0012 \\
$(-5,-1)$ & 5 & 0.0693 & -0.0015 & 0.0688 & -0.0015 \\
$(0,1)$ & 2 & -0.0034 & 0.0001 & -0.0034 & 0.0001 \\
$(0,5)$ & 6 & -0.0156 & 0.0003 & -0.0157 & 0.0003 \\
$(0,10)$ & 11 & -0.0489 & 0.0007 & -0.0425 & 0.0006 \\
$(2,5)$ & 4 & -0.0122 & 0.0003 & -0.0123 & 0.0003 \\
$(2,10)$ & 9 & -0.0390 & 0.0006 & -0.0391 & 0.0007 \\
\hline
\end{tabular}

*Significant 
Table 4. Average abnormal returns (AARs) \& t-values of stocks using both discrete and logarithmic returns for five corporations

\begin{tabular}{|c|c|c|c|c|c|c|}
\hline \multirow{2}{*}{ Days } & \multicolumn{3}{|c|}{ Discrete return } & \multicolumn{3}{|c|}{ Logarithmic return } \\
\hline & AARs & t-value & p-value & AARs & t-value & p-value \\
\hline-20 & 0.001 & 0.250 & 0.818 & 0.001 & 0.238 & 0.827 \\
\hline-19 & 0.005 & 1.099 & 0.352 & 0.005 & 1.081 & 0.359 \\
\hline-18 & 0.011 & 2.416 & $0.095 *$ & 0.010 & 2.292 & 0.106 \\
\hline-17 & -0.001 & -0.291 & 0.790 & -0.001 & -0.312 & 0.776 \\
\hline-16 & 0.017 & 3.812 & $0.032 * *$ & 0.017 & 3.779 & $0.032 * *$ \\
\hline-15 & -0.004 & -0.972 & 0.403 & -0.005 & -1.002 & 0.390 \\
\hline-14 & -0.003 & -0.583 & 0.601 & -0.003 & -0.609 & 0.586 \\
\hline-13 & 0.010 & 2.157 & 0.120 & 0.010 & 2.123 & 0.124 \\
\hline-12 & 0.005 & 1.113 & 0.347 & 0.005 & 1.096 & 0.353 \\
\hline-11 & 0.009 & 2.043 & 0.134 & 0.009 & 2.021 & 0.136 \\
\hline-10 & 0.005 & 1.193 & 0.319 & 0.005 & 1.180 & 0.323 \\
\hline-9 & -0.007 & -1.498 & 0.231 & -0.007 & -1.499 & 0.231 \\
\hline-8 & 0.001 & 0.141 & 0.897 & 0.001 & 0.137 & 0.899 \\
\hline-7 & -0.001 & -0.150 & 0.890 & -0.001 & -0.154 & 0.887 \\
\hline-6 & 0.002 & 0.397 & 0.718 & 0.002 & 0.368 & 0.737 \\
\hline-5 & 0.010 & 2.247 & 0.110 & 0.010 & 2.213 & 0.114 \\
\hline-4 & 0.003 & 0.614 & 0.582 & 0.003 & 0.599 & 0.592 \\
\hline-3 & 0.007 & 1.478 & 0.236 & 0.007 & 1.468 & 0.238 \\
\hline-2 & -0.008 & -1.672 & 0.193 & -0.008 & -1.713 & 0.185 \\
\hline-1 & -0.001 & -0.273 & 0.803 & -0.001 & -0.290 & 0.790 \\
\hline 0 & 0.005 & 1.067 & 0.364 & 0.005 & 1.036 & 0.377 \\
\hline 1 & -0.002 & -0.418 & 0.704 & -0.002 & -0.420 & 0.703 \\
\hline 2 & 0.000 & 0.038 & 0.972 & 0.000 & 0.017 & 0.988 \\
\hline 3 & 0.004 & 0.933 & 0.419 & 0.004 & 0.907 & 0.431 \\
\hline 4 & 0.002 & 0.389 & 0.723 & 0.002 & 0.383 & 0.727 \\
\hline 5 & -0.007 & -1.435 & 0.247 & -0.007 & -1.442 & 0.245 \\
\hline 6 & 0.002 & 0.344 & 0.753 & 0.001 & 0.314 & 0.774 \\
\hline 7 & -0.006 & -1.219 & 0.310 & -0.006 & -1.233 & 0.305 \\
\hline 8 & -0.003 & -0.681 & 0.545 & -0.003 & -0.682 & 0.544 \\
\hline 9 & 0.006 & 1.320 & 0.278 & 0.006 & 1.292 & 0.287 \\
\hline 10 & -0.001 & -0.160 & 0.883 & -0.001 & -0.166 & 0.879 \\
\hline 11 & 0.007 & 1.533 & 0.223 & 0.007 & 1.510 & 0.228 \\
\hline 12 & -0.001 & -0.227 & 0.835 & -0.001 & -0.239 & 0.826 \\
\hline 13 & 0.002 & 0.550 & 0.621 & 0.002 & 0.531 & 0.632 \\
\hline 14 & 0.010 & 2.222 & 0.113 & 0.010 & 2.205 & 0.115 \\
\hline 15 & 0.008 & 1.800 & 0.170 & 0.008 & 1.773 & 0.174 \\
\hline 16 & 0.007 & 1.639 & 0.200 & 0.007 & 1.632 & 0.201 \\
\hline 17 & -0.002 & -0.397 & 0.718 & -0.002 & -0.418 & 0.704 \\
\hline 18 & 0.004 & 0.803 & 0.481 & 0.004 & 0.789 & 0.488 \\
\hline 19 & -0.002 & -0.469 & 0.671 & -0.002 & -0.478 & 0.666 \\
\hline 20 & 0.004 & 0.809 & 0.478 & 0.004 & 0.770 & 0.498 \\
\hline
\end{tabular}

Significance level: $* 10 \%, * * 5 \%$ 
Table 4 shows average abnormal returns of 41 days of event window (20 days prior and 20 days post event) to dividend announcement of five corporations. Market adjusted abnormal return on the dividend announcement day was only 0.5 percent both in discrete and logarithmic forms and not statistically significant. Table 4 also shows no statistically significant average abnormal returns of five companies in the event window.

Table 5 shows cumulative abnormal returns of stocks for five corporations. At the top CARs prior to announcement date are stated. The results show that the firms experienced negative not statistically significant CARs prior to announcement date during event windows of $(-10,-1)$ and $(-5,-1)$. On the other hand CARs around the announcement date, on $(0,1),(0,5)$ and $(0,10)$ periods, are positive but also statistically insignificant. For after dividend announcement periods $(2,5)$ and $(2,10)$, CARs are negative and also statistically insignificant for the firms. Results for five companies also indicated that in all the three time periods including pre, around and post-announcement, CARs are all statistically insignificant for the firms hence again it reveals that dividend announcement do not gain shareholders' value of the firm and it consists with Miller and Modigliani (1961) dividend irrelevance hypothesis [1].

Table 5. Cumulative abnormal returns (CARs) \& t-values of stocks using both discrete and logarithmic returns for five corporation

\begin{tabular}{cccccc}
\hline \multirow{2}{*}{ Period (days) } & Length & \multicolumn{2}{c}{ Discrete returns } & \multicolumn{2}{c}{ Logarithmic returns } \\
\cline { 2 - 6 } & & CARs & t-value & CARs & t-value \\
\hline$(-10,-1)$ & 10 & -0.863 & -1.436 & 0.011 & 0.730 \\
$(-5,-1)$ & 5 & -0.853 & -2.007 & 0.010 & 1.018 \\
$(0,1)$ & 2 & 0.285 & 1.062 & 0.003 & 0.436 \\
$(0,5)$ & 6 & 0.100 & 0.216 & 0.002 & 0.196 \\
$(0,10)$ & 11 & 0.058 & 0.092 & 0.000 & 0.002 \\
$(2,5)$ & 4 & -0.185 & -0.487 & -0.001 & -0.068 \\
$(2,10)$ & 9 & -0.228 & -0.399 & -0.003 & -0.203 \\
\hline
\end{tabular}

*Significant

\section{5- Conclusion}

There has been substantial amount of studies on the performance of stock prices around the announcement of dividend. Despite Walter (1956) and Gordon (1959) that showed stock values depends on expected dividends this study adds to previous research of Miller and Modigliani (1961) research that indicated no impact of dividend on shareholders' value by examining share price behavior around the dividend announcement day.

Findings stated in Table 2 to 5 shows that except few days, market adjusted abnormal return (ARs) and cumulative abnormal returns (CARs) in event window ( -20 days prior and +20 days post) for dividend announcement was not statistically significant. This can be due to the fact that dividend payment information frequently leaks out to the market few days earlier to the dividend announcement made by the corporation. Henceforth, the dividend announcements generally brings no surprise to market and market reacts prior to the announcement of dividend.

Prior to dividend announcement, results for a company found significant only on the days -2 and -5 . Furthermore the results for the sample of 5 companies found significant just 15 prior to the event. The evidences tend to approve that market reacts days prior to day 0 .

All cumulative abnormal returns for the period of 10 days before and 10 days after announcement day is insignificant. Results in Table 2 and 5 demonstrations that, investors do not gain value of the announcement of dividend. Hence, in general the results consistent with the Miller and Modigliani (1961) dividend irrelevance hypothesis.

Based on 5 companies listed in NASDAQ which pay out special dividends between 2014 and 2018, the results suggest that the influence of dividend announcement on stock prices are not strong in NASDAQ Stock Exchange. So, Corporations may not able to signal company's future earning through the announcement of their dividend and like to keep paying regular dividends for their good standing. It is however vital to examine more whether dividends carry any information like future earnings. Future researches on the dividend information hypothesis would assess the current finding of this study that supports the dividend irrelevancy proposition NASDAQ stock exchange.

\section{6- Conflict of Interest}

The author declares that there is no conflict of interests regarding the publication of this manuscript. In addition, the ethical issues, including plagiarism, informed consent, misconduct, data fabrication and/or falsification, double publication and/or submission, and redundancies have been completely observed by the authors. 


\section{7- References}

[1] Porterfield, James TS. "Dividends, Dilution, and Delusion." Harvard Business Review 37, no. 6 (1959): 56-61.

[2] Miller, Merton H., and Franco Modigliani. "Dividend Policy, Growth, and the Valuation of Shares.” The Journal of Business 34, no. 4 (January 1961): 411. doi:10.1086/294442.

[3] Gordon, M. J. "Dividends, Earnings, and Stock Prices.” The Review of Economics and Statistics 41, no. 2 (May 1959): 99-105. doi:10.2307/1927792.

[4] Walter, James E. "Dividend Policies and Common Stock Prices." The Journal of Finance 11, no. 1 (March 1956): 29. doi: $10.2307 / 2976527$.

[5] Brennan, Michael J. "Taxes, market valuation and corporate financial policy." National tax journal 23, no. 4 (1970): $417-427$.

[6] Litzenberger, Robert H., and Krishna Ramaswamy. "The Effect of Personal Taxes and Dividends on Capital Asset Prices.” Journal of Financial Economics 7, no. 2 (June 1979): 163-195. doi:10.1016/0304-405x(79)90012-6.

[7] Ross, Stephen A. “The Determination of Financial Structure: The Incentive-Signalling Approach.” The Bell Journal of Economics 8, no. 1 (1977): 23. doi:10.2307/3003485.

[8] Ogden, Joseph P. “A Dividend Payment Effect in Stock Returns Joseph P. Ogden (State University of New York at Buffalo).” Financial Services Review 4, no. 1 (1995): 63. doi:10.1016/1057-0810(95)90024-1.

[9] Stevens, Jerry L., and Manuel L. Jose. "The Effects of Dividend Payout, Stability, and Smoothing on Firm Value.” Journal of Accounting, Auditing \& Finance 7, no. 2 (April 1992): 195-212. doi:10.1177/0148558x9200700207.

[10] Kato, Kiyoshi, and Uri Loewenstein. “The Ex-Dividend-Day Behavior of Stock Prices: The Case of Japan.” Review of Financial Studies 8, no. 3 (July 1995): 817-847. doi:10.1093/rfs/8.3.817.

[11] Loughlin, Phi. “The Effect of Dividend Policy on Changes in Stockholders' Wealth.” A PhD Thesis, (1983): 1609-1609.

[12] Sealy, Nicholas R, and Rory F Knight. "Dividend Policy, Share Price and Return: A Study on the Johannesburg Stock Exchange." Investment Analysts Journal 16, no. 29 (May 1987): 33-47. doi:10.1080/10293523.1987.11082259.

[13] Uddin, Md Hamid, and Golam Mohammed Chowdhury. "Effect of dividend announcement on shareholders' value: Evidence from Dhaka Stock Exchange." Journal of Business Research 7, no. 1 (2005): 61-72.

[14] Lotfi, Taleb. "Dividend Policy in Tunisia: A Signalling Approach.” International Journal of Economics and Finance 10, no. 4 (March 3, 2018): 84-94. doi:10.5539/ijef.v10n4p84.

[15] Chatterjee, Chanchal, and Paromita Dutta. "Price Behaviour around Dividend Announcements in the Indian Equity Market in the Existence of Corporate Dividend Tax." Global Business Review 18, no. 2 (March 16, 2017): 402-415. doi:10.1177/0972150916668609.

[16] Legenzova, Renata, Otilija Jurakovaite, and Agne Galinskaite. "The Analysis of Dividend Announcement Impact on Stock Prices of Baltic Companies.” Central European Business Review 6, no. 1 (2017): 61-75. doi:10.18267/j.cebr.173.

[17] Felimban, Razaz, Christos Floros, and Ann-Ngoc Nguyen. "The Impact of Dividend Announcements on Share Price and Trading Volume.” Journal of Economic Studies 45, no. 2 (May 14, 2018): 210-230. doi:10.1108/jes-03-2017-0069.

[18] Chaabouni, Ines. "Impact of dividend announcement on stock return: A study on listed companies in the Saudi Arabia financial markets." Business and Management 9, no.1 (2017): 37-44.

[19] Ozo, Friday Kennedy, and Thankom Gopinath Arun. "Stock Market Reaction to Cash Dividends: Evidence from the Nigerian Stock Market.” Managerial Finance 45, no. 3 (March 11, 2019): 366-380. doi:10.1108/mf-09-2017-0351.

[20] Frensidy, Budi, irene josephine zakaria, and Ignatius Roni Setyawan. "Price Formation Around Cum Date Dividend Announcement: Empirical Evidence in Indonesian Stock Exchange.” SSRN Electronic Journal 22, no.3 (2016): 106-118. doi:10.2139/ssrn.2711644.

[21] Brown, Stephen J., and Jerold B. Warner. “Using Daily Stock Returns.” Journal of Financial Economics 14, no. 1 (March 1985): 3-31. doi:10.1016/0304-405x(85)90042-x.

[22] NASDAQ. Available online: https://www.nasdaq.com/symbol/eqix/dividend-history, (Accessed on 1 December 2018).

- Available online: https://www.nasdaq.com/symbol/uhal/dividend-history, (Accessed on 1 December 2018).

— Available online: https://www.nasdaq.com/symbol/cme/dividend-history, (Accessed on 1 December 2018).

— Available online: https://www.nasdaq.com/symbol/klac/dividend-history, (Accessed on 1 December 2018).

— Available online: https://www.nasdaq.com/symbol/trow/dividend-history, (Accessed on 1 December 2018).

[23] MacKinlay, A. Craig. "Event studies in economics and finance." Journal of economic literature 35, no. 1 (1997): 13-39. 